\title{
Conscription as Regulation
}

\section{Citation}

Mulligan, C. B. and Andrei Sheifer. 2005. Conscription as Regulation. American Law and Economics Review 7 (1): 85-111. doi:10.1093/aler/ahi009.

\section{Published Version}

doi:10.1093/aler/ahi009

\section{Permanent link}

http://nrs.harvard.edu/urn-3:HUL.InstRepos:27867136

\section{Terms of Use}

This article was downloaded from Harvard University's DASH repository, and is made available under the terms and conditions applicable to Other Posted Material, as set forth at http:// nrs.harvard.edu/urn-3:HUL.InstRepos:dash.current.terms-of-use\#LAA

\section{Share Your Story}

The Harvard community has made this article openly available.

Please share how this access benefits you. Submit a story.

Accessibility 
NBER WORKING PAPER SERIES

CONSCRIPTION AS REGULATION

Casey Mulligan

Andrei Shleifer

Working Paper 10558

http://www.nber.org/papers/w10558

\author{
NATIONAL BUREAU OF ECONOMIC RESEARCH \\ 1050 Massachusetts Avenue \\ Cambridge, MA 02138 \\ June 2004
}

Pak Shun Ng helped us gather information from The Military Balance and other sources, and gave us good advice on several other aspects of the project. We have also benefitted from seminars at the University of Chicago, and discussions over the years with Gary Becker and John Warner. Mulligan gratefully acknowledges the financial support of the University of Chicago's Stigler Center for the study of the Economy and the State. The views expressed herein are those of the author(s) and not necessarily those of the National Bureau of Economic Research.

C2004 by Casey Mulligan and Andrei Shleifer. All rights reserved. Short sections of text, not to exceed two paragraphs, may be quoted without explicit permission provided that full credit, including (C) notice, is given to the source. 
Conscription as Regulation

Casey Mulligan and Andrei Shleifer

NBER Working Paper No. 10558

June 2004

JEL No. D72, D73, H56, K2

\section{ABSTRACT}

We examine the practice of military conscription around the world from the perspective of two standard theories, and a new one, which emphasizes the fixed cost of introducing and administering the draft as a deterrent to its use. We find that, holding the relative size of the military constant, higher population countries are more likely to use the draft. We also find that French legal origin countries, which we see as facing lower fixed and variable administrative costs, are more likely to draft than are common law countries. Conscription does not seem to be influenced by democracy, and is influenced by the deadweight costs of taxation only in countries with very large militaries. The results suggest that fixed costs of introducing and administering new regulations may be an important determinant of their use.

Casey Mulligan

University of Chicago

Department of Economics

1126 East $59^{\text {th }}$ Street, \#506

Chicago, IL 60637

and NBER

c-mulligan@uchicago.edu

Andrei Shleifer

Harvard University

Department of Economics

M9 Littauer Center

Cambridge, MA 02138

and NBER

ashleifer@harvard.edu 


\section{Introduction}

Every military in the world employs at least some professional volunteer soldiers. Somewhat fewer than half of all countries rely entirely on such volunteers, while the rest draft some of their military personnel. According to the International Institute for Strategic Studies, in 1995 the militaries of the countries that used conscription ranged from $25 \%$ draftees in South Korea and Denmark to $89 \%$ draftees in Switzerland and Senegal. Why is there so much variation across countries in the importance of conscription in meeting military manpower needs?

Traditional public economics answers this question by postulating a tradeoff between selection (the draft inducts the wrong people into the military) and deadweight costs of taxation (as a tax in kind, the draft saves on the cash costs of a military that must be otherwise financed through distortionary taxes). This approach to the draft has been pursued, among others, by Friedman (1967), Lee and McKenize (1992), Ross (1994), and Warner and Asch (1995), and may explain why conscription is more likely when the demand for troops is high. But as both Ross (1994) and our work below show, this approach has been otherwise unsuccessful in explaining the variation of conscription patterns across countries.

In this paper, we analyze conscription from the perspective of startup and enforcement costs. Specifically, we argue that the organization of conscription relative to the already available volunteer army requires substantial incremental fixed costs. Some of these costs are political: interest groups favoring conscription must organize and translate their agenda into law. Other fixed costs of running the draft are administrative. A conscription law must be drafted and passed. A census of potential draftees must be prepared. If the draft is universal, offices must be set up throughout the country and staffed with draft officials, medical doctors (who deal with medical exemptions), and enforcers who pursue draft dodgers. If the draft allows for various exemptions or replacements, further staff must be recruited to administer these procedures. Relative to an all volunteer army, where potential recruits show up and willingly cooperate with all procedures, conscription demands a substantial fixed cost on top of what is already being spent recruiting volunteers.

The emphasis on the fixed costs of organizing the draft follows from our earlier work on regulation, which modeled the fixed cost of drafting and enforcing new laws (Mulligan and Shleifer 2003). This theory yields two fundamental implications. First, it predicts that countries with larger 
populations, which can spread these fixed costs over more people, are more likely to have conscription, holding constant their military manpower needs. Second, it predicts that countries for which the incremental administrative fixed costs are lower are more likely to have conscription.

The first prediction can be tested using data on population. But how would one compare administrative costs of enforcing additional regulations, such as conscription, across countries? Our proxy for the level of incremental administrative costs is the historical origin of a country's laws. In a series of papers, La Porta et al. $(1997,1998,1999)$ argue that legal systems of most countries have relatively few "origins." These origins include the laws of England (common law), and civil laws of France, Germany, Scandinavia, and U.S.S.R.. From the mother countries, the legal traditions have been transplanted through conquest (mostly by Napoleon and the Soviets) and colonization. As a consequence, legal developments of most countries in the world have been shaped by their involuntarily acquired legal systems. In particular, in their legal structures, common law countries tend to rely to a greater extent on contracts and decentralized dispute resolution in courts, and civil law countries to a greater extent on regulation and even state ownership.

But transplantation did not just affect the codes available at the time; it influenced the patterns of social control of business used in countries from different legal origins for reasons of "regulatory complementarity." Once a country used a particular way of meeting a social goal, the human capital of its administrators and the structure of its existing institutions made it cheaper to use a similar approach in a new area of government intervention. As a consequence, compared to the common law countries, civil law countries tended to use heavier government regulation of a whole range of activities from entry by new firms (Djankov et al. 2002) to labor markets (Botero et al. 2003). By relying on the administrative apparatus of the state to solve some social problems, the French and other civil law countries tended to rely on it to address others as well.

This logic is directly relevant to conscription. Following Woloch (1994), we argue below that the French administrative state - because it was already so pervasive-lowered the incremental cost of organizing the draft (in France, in the countries that Napoleon brought his laws to, and in their colonies). As a consequence, these countries should be more likely to use conscription than the common law countries. To the extent that legal origin predicts the reliance on the draft, then, it is a direct test of the enforcement theory of conscription, that puts the fixed costs at center stage. Below, we examine this prediction empirically.

In the next section, we summarize the available theories of the draft, and spell out our 
approach. We also provide some historical background on the early modern use of conscription under Napoleon. Section III presents our findings. Section IV concludes.

\section{Theories of Conscription}

Prior to Napoleon, armies were typically staffed by voluntary enlistments or by impressment - the forced recruitment of individuals with little or no compensation or regulation of service terms or length. In contrast to impressment, we define conscription or "the draft" to be the legal and regulated form of forced labor for the state, usually in the military, but sometimes in other activities, such as jury duty. ${ }^{1}$ In recent years, only very few countries have used impressment, and most militaries are staffed by some combination of volunteers - present in every military - and conscripts. Among the 68 countries in our sample having conscription (and reporting data on the number of draftees), the typical military force is about half volunteer and half drafted. Hence, the relevant policy question is not a volunteer versus a draft system, but whether to have a draft system to supplement the volunteer system. With this in mind, for brevity's sake we refer to the all-volunteer systems as "volunteer" and mixed systems as "conscription."

How should and do polities decide whether or not to add conscription? One theory emphasizes the trade-off between the selection and the deadweight costs of taxation (e.g., Friedman, 1967; Lee and McKenzie, 1992; Ross, 1994; Warner and Asch, 1995). Obviously, any soldier has an opportunity cost regardless of how he is recruited, but the volunteer system compensates him at least for his opportunity cost, ${ }^{2}$ and the compensation is financed with taxes. For the usual "deadweight cost" reasons, taxes cost taxpayers more than they deliver to the Treasury, so that on

${ }^{1}$ The Old Testament mentions impressment "There was hard fighting against the Philistines all the days of Saul; and when Saul saw any strong man, or any valiant man, he attached him to himself." (1 Samuel 14:52), but also mentions regulatory ingredients for conscription, such as a census of able men aged 20+ (Numbers 1:1-3), and exemptions from military service (Deuteronomy, chapter 20). In Sweden, Prussia, and the United States, some of the manpower policies prior to Napoleon may also be described as conscription (Mjoset and Van Holde, 2002, pp. 17f; Kestnbaum, 2000, but see Carleton, 1968, for another interpretation).

${ }^{2}$ If the military cannot price discriminate, all personnel in the volunteer system are paid the opportunity cost of the soldier with the highest opportunity cost. 
this account a volunteer system may be more expensive. ${ }^{3}$ The volunteer system is also selective, because it enlists only the qualified persons with lowest opportunity cost. If conscription selects less well (as defined by efficiency or some other criteria), then there is a tradeoff between deadweight costs and selection. Proxies for tax deadweight costs such as the amount of nonmilitary government spending, the age of the population, and economic openness (which may be associated with higher deadweight costs) or economic development (which may be associated with lower deadweight costs) should help predict which countries use the draft.

The theory presumes that conscription selects sufficiently different recruits than does a volunteer system, or else there is no real tradeoff. In theory, the two systems could select the same recruits if draftees were allowed to pay a commutation fee, or supply a substitute, as an alternative to serving their time with the military, because persons with high opportunity costs would pay the fee or purchase a substitute and the military would be left with the low opportunity cost persons. Even without these fees, a military draft does not have to be random or universal, but could try by regulation (namely a list of rules for exemptions and deferments) to mimic market selection (Warner and Asch, 2001, p. 173). Indeed, many conscription systems exempt women, college students, fathers, disabled, sons from rich families, older people, and others who might be expected to have a comparative advantage in civilian activities. But the theories assume without explanation that in practice conscription does not select enough, and hence model it as random or universal selection.

A second theory holds that economic development and democratization are associated with an increased disdain for arbitrary and capricious use of force by the state, which moves policy away from impressment, although the substitute could be either conscription or a volunteer system. But if citizens are more collective-minded in a democracy, they would be more willing to serve as conscripts, raising the likelihood of the draft (Levi 1997). People may also desire the military to be a cross-section of the polity, a goal which may be more easily achieved with universal or random selection than with market selection. Hence, democracy might help predict both the use of

${ }^{3}$ Conscription also has deadweight costs, as members of the draft-eligible population emigrate or change their behavior in order to qualify for educational, occupational, and other exemptions (President's Commission, 1970, p. 33). These costs could be large for random selection systems, because they violate the principle of tax smoothing. Sjaastad and Hansen (1970) estimate large deadweight costs of the draft for the U.S. in the 1960's. 
conscription and its "fairness." Along different lines, but with the same prediction, the President's Commission (1970, p.25) suggests that democracies may be more likely to draft because the costs of a draft are concentrated on a minority of voters. These predictions are testable by asking whether democracy predicts the incidence of conscription.

The third theory of conscription, which is new to this paper, emphasizes the startup and enforcement costs of alternative public responses to social problems. Different public policies for addressing social needs, including raising a military, are associated with very different marginal and fixed social costs. For example, on the margin of how many military personnel to recruit, the volunteer system has rising marginal costs both in terms of opportunity and deadweight costs. ${ }^{5}$ The marginal costs of conscription-with-buyout is definitely lower, because it has the same opportunity cost and no deadweight cost of taxes. The marginal costs of other conscriptions systems may also be lower.

But conscription also has significant fixed adoption, administration, and enforcement costs. The adoption costs include reaching a political consensus on not only how many people should serve in the armed forces, but the fraction of the force to be drafted, the length of service, the population subject to the draft, occupation-specific terms of service, exemptions, deferrals, and possibilities for commutation fees, substitutes, and conscientious objection. The political costs may be especially significant for conscription policy because some of the issues involved are so controversial. Administrative and enforcement costs include deriving algorithms for enumerating the population subject to the draft, setting up and staffing offices throughout the country to administer the draft, verifying qualifications for exemptions, including medical ones, establishing institutions specializing in catching draft dodgers, and policing the system itself to assure fairness and avoid corruption.

Conscription transforms some of the marginal costs of the volunteer army into fixed costs,

${ }^{4}$ Levi $(1997$, pp. 103, 106) admits that the time series data are less than fully supportive of this hypothesis, because the movement from replacement and commutation systems to universal or random selection may have preceded democratization. Mulligan, Gil, and Sala-iMartin (2004) explain why democracies choose the same policies as non-democracies.

${ }^{5}$ If the volunteer system has setup and enforcement costs that are "fixed" in the sense of being independent of the number of recruits, they are irrelevant for our analysis because all militaries have a least some volunteers. We also believe that the fixed costs of volunteer labor are small, because volunteer labor is hired by very small businesses and households. 
especially for the less selective conscription systems. For example, a small volunteer army might maintain just a few recruiting stations (e.g., perhaps just one located near the military headquarters), and plan for the training of a particular type of enthusiastic and able recruits. As the volunteer force grows, it would open additional recruiting stations, learn to train and integrate a more heterogeneous group of recruits, and incur the political costs associated with such changes in the force composition. These additional recruiting costs are marginal. But a universal or random conscription system pays these costs regardless of the number of troops to be recruited, because the system recruits a crosssection of the population.

The fixed costs of conscription vary systematically with the type of conscription system, and are not limited to budgeted governmental costs. We mentioned the political mobilization costs, but there are also private sector costs, especially under the more complex conscription systems with commutation fees, replacement, and various exemptions. ${ }^{6}$ A replacement system creates a demand for an infrastructure helping to match draftees with potential replacements, and private sector intermediaries were common in the U.S. and several European countries using replacement systems (Moore, 1924, pp. 30f; Levi, 1997, p. 102). Commutation fee systems create a demand for financing the fee. Insurance markets even paid awards, in the amount of the commutation fee or market replacement price, to insured persons who were chosen by the draft lottery (Levi 1997, p. 89, 91)! These private behaviors then create additional regulatory costs for the government. ${ }^{7}$ For example, under the replacement system, persons have been known to contract themselves as a substitute (in exchange for the substitute fee), go AWOL, and then contract to substitute for another conscript (Moore, 1924, pp. 32f).

Consider a simple mathematical model of the choice of one of four military manpower systems: all-volunteer, universal or random conscription, conscription with exemptions, and conscription with replacement or commutation. We index these methods $i=v, u, x$, and $r$,

${ }^{6}$ Levi (1997, p. 100) concludes "The costs to the government, bureaucratically and politically, of administering the draft were high enough without the added costs created by commutation."

${ }^{7}$ Levi (1997, pp. 89-92) explains how "[insurance schemes were] prone to fraud and corruption, ... and the actions of agents who offered the insurance and located replacements became even more suspect over time" and how "government was called upon to regulate a market quite difficult to regulate." 
respectively (for volunteer, $u$ niversal, conscription with exemptions, and conscription with replacements). $c(m)$ denotes the rising average opportunity cost of recruiting the fraction $m$ of the population with the lowest opportunity cost. Recruitment method $i$ has total cost including fixed adoption, administration, and enforcement costs denoted $\rho_{i}$, as well as opportunity, deadweight, and other variable costs denoted $m N \delta_{i} c(m)$. $N$ denotes total population, and $m$ military personnel per capita, so $m N$ denotes total military personnel. $\delta_{i} c(m)$ is the net average variable cost per soldier, which includes the opportunity $\operatorname{cost}\left(\delta_{i} \geq 1\right)$, and depends on the recruitment method. We assume:

$$
\begin{aligned}
& 0=\rho_{v}<\rho_{u}<\rho_{x}<\rho_{r} \\
& \delta_{v}>\delta_{u}>\delta_{x}>\delta_{r}=1
\end{aligned}
$$

The ordering of the $\rho$ 's in (1) was already explained, although our theory does not strongly favor it over an ordering $\rho_{v}<\rho_{u}<\rho_{r}<\rho_{x}$ because the exemption system could have the highest fixed cost depending on the nature of the exemptions and the resources needed to regulate the market for substitutes or commutation fees. Under some theories, the variable cost of recruiting under the replacement system is simply the opportunity $\operatorname{cost} c(m)$ - hence we set $\delta_{r}=1$ - and the variable cost of the volunteer system is the sum of the opportunity and deadweight-tax costs, so $\delta_{v}$ is larger than one and reflects the deadweight costs of taxes and the market condition that the marginal soldier must be paid his opportunity cost. ${ }^{8}$ We assume that $\delta_{u}$ and $\delta_{x}$ are in the interval $\left(1, \delta_{v}\right)$ because these conscription systems (probably) economize on the deadweight costs of taxes but imperfectly select soldiers according to their opportunity cost.

We also assume that each of the conscription systems achieves the lowest cost for some $m$, $N$. If not, we would not observe one (or more) of the systems because it would be strictly dominated by some combination of the others. With this assumption, the recruitment system choice can be displayed graphically, as in Figure 1. ${ }^{9}$ The optimal recruiting cost curve is the envelope of the cost curves for each system, which means that size as measured by $m$ or $N$ affects the type of system in

${ }^{8}$ Allow for tax deadweight costs to be convex in $m$ does not affect the qualitative implications of our model.

${ }^{9}$ Algebraically, our assumption means $\frac{\rho_{u}}{\delta_{v}-\delta_{u}}<\frac{\rho_{x}-\rho_{u}}{\delta_{u}-\delta_{x}}<\frac{\rho_{r}-\rho_{x}}{\delta_{x}-1}$. 
a particular order. For the smallest populations and forces, the volunteer system is the least costly. After that, universal or random conscription minimizes cost. Larger forces and populations use systems with exemptions, and the largest systems with replacements or commutations.

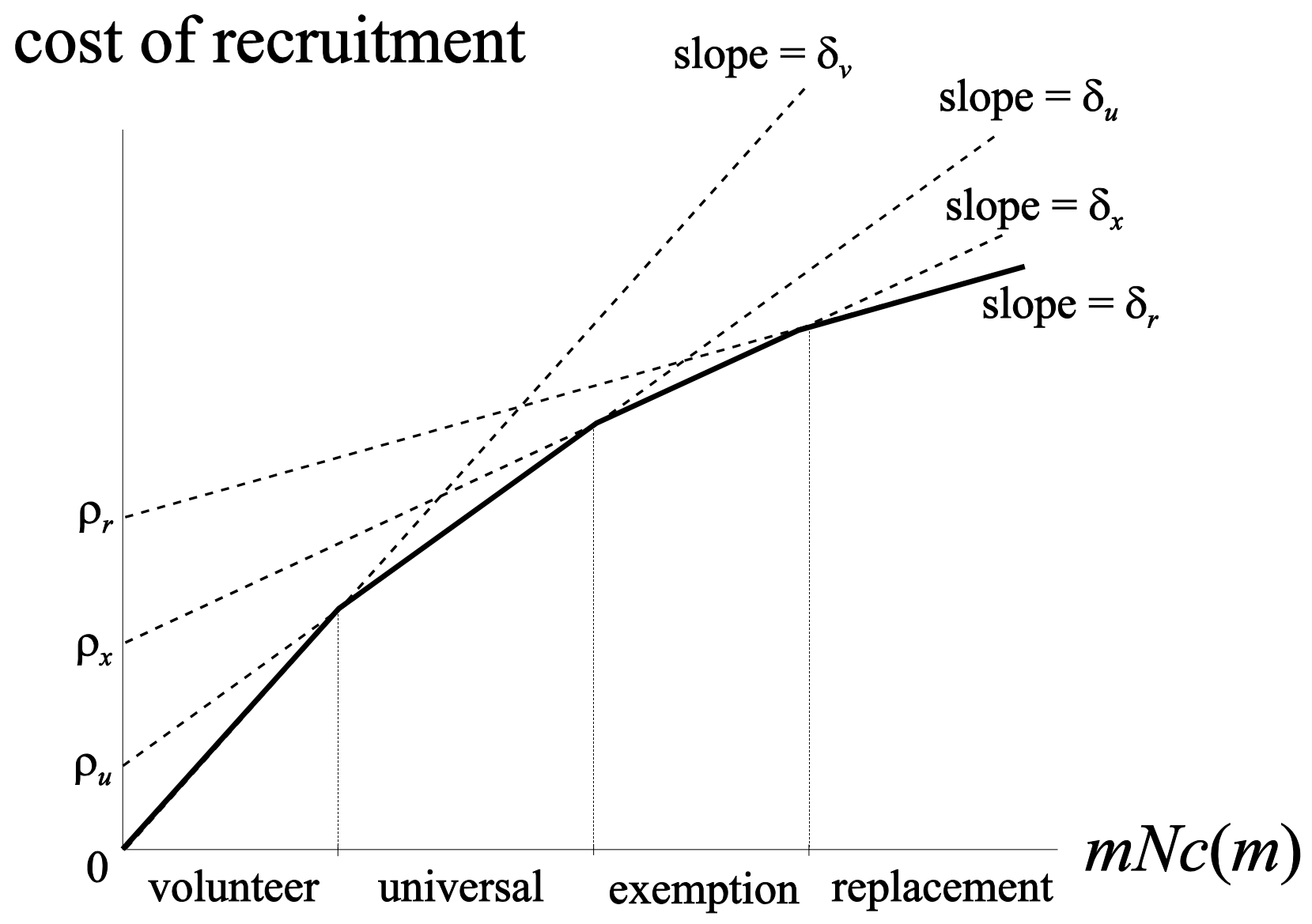

Figure 1 The Military Recruitment System, as Determined by the Size and Composition of the Force

The previous economic theories have set all of the $\rho$ 's equal to zero, so for them the size of the force matters only because $c(m)$ rises with $m$. Although our model has $N$ 's effect smaller than $m$ 's, $N$ 's effect is still positive. Higher population countries are more likely to have conscription, and, conditional on having conscription, more likely to have the type with exemptions or replacements. In our view, $m$ and $N$ matter even with $c$ held fixed because of scale economies in the adoption, administrative, and enforcement costs. 
There is an additional, perhaps more surprising, implication of the model. Suppose we compare two countries, and the first has lower fixed costs of administering any incremental government regulation, including the different kinds of conscription, perhaps because it has already established an extensive apparatus of government control that can be utilized for conscription as well. Then the theory predicts that the country with lower fixed costs is more likely to use conscription, and, conditional on using conscription, more likely to use the type with exemptions or replacements. So how can we compare fixed costs across countries?

Motivated by the work of Woloch (1994) on Napoleonic conscription in France, we suggest that legal origin of a country's laws is a proxy for the level of fixed regulatory costs. Woloch describes how, following the Revolution, France established a pervasive administrative state. The country was divided into 80 departments, which were further subdivided down to the village level, with each level administered through a vertical hierarchy and directly accountable to the center. The administration was involved in budgets, police, roads, courts, primary education, hospitals, and some social welfare. Given the level of penetration of the state administration into national life, Woloch argues, draft administration was only an extension of the existing structures. "By Napoleon's choice, conscription constituted the ultimate frontier of state building, of the articulation of the administrative state projected by the Revolution... Conscription became the state's obsession, the preoccupation of officials up and down the government hierarchy...”(p. 433). Conscription, according to Woloch, was tremendously successful in raising armies. In our, more prosaic, view, conscription was used successfully in France because the initial administrative innovations created sufficiently invasive governmental structures that could then run the draft without prohibitively expensive incremental mechanisms of assuring compliance.

We argue that the French legal origin is, in part, a shorthand for this administrative/regulatory approach to addressing social problems (Djankov et al. 2003). Through Napoleonic conquest and colonization, it was then transplanted to much of continental Europe, all of Latin America, North and West Africa, and parts of Asia. Scandinavian, German, and Socialist civil law countries have developed similar approaches to social intervention. England and its colonies, in contrast, did not develop such an administrative state at the early stages, and therefore we take common law to be a shorthand for the more decentralized approach to solving social problems. If the transplantation of the administrative/regulatory approach to addressing social problems reduces the fixed (and perhaps also the variable) costs of dealing with incremental ones, 
then our theory predicts that common law countries should be less likely to draft than civil law countries. Moreover, conditional on using conscription, common law countries should be less likely to allow exemptions and replacements than do civil law countries.

Our theory adds fixed costs ( $\rho$ 's) to the variable costs $(\delta$ 's) of the previous economic theories. Obviously, our theory looks most like the previous ones when the variable costs are large relative to the fixed costs, as in countries with large armed forces. Perhaps this, together with the fact that most countries have small armed forces, explains why it has been hard to find an important cross-country correlation between conscription and proxies for the deadweight cost of taxes (see Ross, 1994, and our estimates below). Perhaps this, together with the fact that the deadweight cost of taxes has fallen secularly, also helps explain why there has been a secular decline in the wartime use of replacement and commutation conscription systems (these were common in the $19^{\text {th }}$ century, and eliminated from every European country in the first half of the $20^{\text {th }}$ century). This also suggests that deadweight costs would matter more in cross-country samples selected on the basis of large force sizes - a prediction which we verify below.

\section{Quantifying Military Manpower Systems}

\section{III.A. Data Sources}

We quantify military recruitment policy in a variety of dimensions, using a variety of sources. Our first source is the 1985, 1990, and 1995 editions of the annual The Military Balance from The International Institute for Strategic Studies. Its measures include whether or not people were drafted into military service, the number of months of service required, number of people in the Armed Forces, and number of conscripts in the Armed Forces. We cross-checked the 1995 edition with the United Nations Commission on Human Rights $(1997,1999)$ and War Resisters' International (WRI, 1998), and found potential discrepancies for 33 countries. For each of those countries, we checked the entire history from 1985 to 1995 with 1upinfo.com's encyclopedia and child-soldiers.org, and resolved the discrepancy as explained in a separate appendix ( $\mathrm{Ng}$ and Mulligan, 2004).

For the countries with conscription, we obtain information about selection procedures from

War Resisters' International (1998). This source indicates whether it is legal, or commonly practiced, for conscripts to buy themselves out of military service. It also indicates whether college 
(or, in a few cases, high school) students are exempt, have shorter terms of service, or have more flexible terms of service. All of our sources are non-governmental organizations. Perhaps this gives our data objectivity in some dimensions, but these organizations may also have agendas like world peace, toppling dictators, or publicizing human rights violations.

For the purposes of coding a country-year as having conscription or not, two judgements are required. First, does a country-year have conscription merely because it has some of the legal components in place (like a clause in the constitution or, as in the U.S. in 2003, a system of registering the names of young men), or does it actually have conscripts serving? Our data indicates the latter more easily, which fortunately may be the better judgement theoretically. We thus code a country-year as no conscription if (1) The Military Balance (supplemented with our other sources as indicated by the appendix) indicates no conscription in any sense of the word, (2) The Military Balance deems the policy lax enough to report "no conscription," which it appears to do when a conscription law and/or partial system exists but there are few if any conscripts in the armed forces, or (3) our other sources clearly indicate that there were zero conscripts.

The second judgement is whether to distinguish the "modern" legally based form of conscription from impressment or press-ganging. For the purposes of our model, legal conscription is very different than impressment because only the former has the political and administrative costs of drafting, adopting, and enforcing the legislation and should thereby be coded as conscription. This distinction is less important for other models, and ideally we would have a separate coding scheme which classified impressment systems as "having conscription" rather than not having it. In practice, we are at the mercy of our sources, which (especially the Military Balance) might not mention the practice of conscription in countries where it has no legal basis, and/or impressment and other informal means are used on a small scale. ${ }^{10}$ However, even though impressment was common historically, we suspect that in today's world impressment is overwhelmingly dominated by volunteer systems and legal conscription as sources of military manpower.

${ }^{10}$ According to WRI (1998), impressment was used in Afghanistan under the Taliban, Burma, Cambodia, Guatemala, and the Democratic Republic of Congo before their independence. WRI reports that impressment as well as legal conscription are used in Angola, Armenia, Azerbaijan, Columbia, Georgia, Lebanon, Libya, Paraguay, Peru, Sudan, Tajikistan, and Venezuela. Rebel groups in some countries use impressment. 
The fraction of countries with conscription fell slightly from $63 \%$ in 1985 to $59 \%$ in $1995 .^{11}$ This decline is somewhat greater if we exclude the new countries created by USSR's breakup (many of which have conscription). It might also be greater if we looked at the period 1985-2004 during which many Western European countries dropped conscription.

WRI says that 95 countries have a draft c. 1996 and, among them, most (56) have easier terms of service for college (or sometimes high school) students. 32 of the 56 permit students to postpone their service - a nice benefit in Western Europe where most ended up dropping conscription within a few years. 13 countries have shorter terms for college students, and 11 countries exempt them altogether. ${ }^{12}$ Fewer countries seem to have conscripts buying their way out of service. 13 countries, including China, Iran, Iraq, and Turkey, have legal provisions for buying out. ${ }^{13}$ At least 17 countries are reported to have large numbers of conscripts paying bribes to obtain fake medical records, military service certificates, or other exemptions. Military Balance says that two countries (Iceland and Panama) had zero troops (and no conscription) 1985-95; for simplicity we exclude them, although we have verified that their exclusion does not affect our results.

Following Ross (1994), we use the size of the Armed Forces as a proxy for (the inverse of) the deadweight cost of conscription - namely that a draft system is less likely to select the wrong people when most of the people are going to serve anyway. In our analysis, there is another reason why conscription is better for a larger force - the fixed cost of the draft system is amortized over more draftees. Our explanatory variables also include a variety of country characteristics like economic development, government spending, population age, etc., whose sample statistics are shown in our appendix and whose sources are described by Mulligan and Sala-i-Martin (2004).

${ }^{11}$ WRI (1998) reports 56\% of countries having conscription c. 1996. The percentages reported in the text are the year coefficients from a regression of conscription on country and year dummies, in order to account for the addition of some countries to the same in 1990 and 1995.

${ }^{12}$ Three countries actually have tougher military service for college students (Philippines, Tanzania, and Uganda), where military training is part of the college curriculum.

${ }^{13}$ For 2 or 3 of the 13 countries, it is unclear whether the buying out was legal, or common and illegal. Nine of the 13 buyout countries are among the 56 countries having special provisions for college students. 


\section{III.B. Predictors of Manpower Systems}

Table 1 displays cross-country regressions of having conscription on population, legal origin, development, etc. The first three columns are probit regressions, measuring conscription from Military Balance for 1985, 1990, 1995, respectively. The fourth and fifth columns use WRI. THe last three columns are OLS regressions, with the dependent variable being the fraction of the available three years that the country had conscription (i.e., takes on values $0, .33, .67,1$ ). The sixth column adds the control for per capita income, the seventh compares just French and English legal origin countries. In all specifications, we control for the size of the armed forces relative to the population of males aged 15-24. We are thus looking at the decision of whether to add conscription to a volunteer army, taking manpower needs as given. ${ }^{14}$ As we explain further below, this control may account for international differences in war risks, differences in the belligerency of neighbors, etc., because they affect the size of the military, but otherwise not the way in which it is recruited.

Specifications (1)-(7) show a huge effect of legal origin on conscription, with the likelihood of conscription 50 percentage points lower in common law countries than in other countries. This result is broadly supportive of our prediction, and of the interpretation of legal origin as, in part, a shorthand for fixed costs of incremental regulation. ${ }^{15}$ Population has a large effect and, as expected, in the opposite direction of common law. This result, as well, is predicted by our theory.

By themselves, specifications (1)-(4) may be hard to interpret because they exclude several very small countries neglected by POLITY IV (2000), and do not control for GDP per capita. On the first point, we note that most countries missing from POLITY are also missing from The Military Balance. Eight of them are studied by WRI, and only one has conscription. Regression (5) includes the five countries missing from POLITY but found in The Military Balance (and thereby having a measure of armed forces), and the coefficient estimates are essentially the same as in specification (4). On the second point, notice that specifications (6)-(7) exclude, among other things, the ten countries missing from the Penn World Tables. Since all ten of these countries draft and eight are

\footnotetext{
${ }^{14}$ But note that interpreting the magnitude of the coefficient on armed forces requires an estimate of the degree to which armed forces affect conscription, rather than conscription affecting the size of the military.

${ }^{15}$ Levi (1997, p. 92) explains how "The costs to government of implementing and using replacement decreased in some ways over time, as central government enlarged its bureaucratic and coercive reach."
} 
communist, excluding them has a dramatic effect on the communist coefficient but provides no convincing evidence that GDP per capita affects conscription.

What about the other theories of conscription? Specifications (1)-(7) already suggest that the deadweight costs of taxes do not explain much of the cross-country variation. For example, countries with more elderly are expected to have higher deadweight costs of taxes, because their governments spend a lot (especially on public pensions), but the partial correlation between conscription and the elderly population share is statistically insignificant. Richer countries probably collect taxes more efficiently, but they are not much more likely to use an all-volunteer system. However, specification (8) shows that both of these potential proxies for the deadweight costs of taxes are correlated with conscription - in the expected direction - for the sample of 32 countries recruiting more than $10 \%$ of military-aged males. Perhaps this is consistent with the hypothesis that conscription is more sensitive to deadweight costs in countries with very large armed forces.

Tables 2 and 3 use the WRI data to explore determinants of the various kinds of conscription systems. As discussed above, manpower systems can be ordered according to their adoption and enforcement costs: $100 \%$ volunteer, plain conscription, conscription with college exemptions (but no buyouts), and conscription with buyouts. The first thing to notice from Table 2 's cross-tab is that only nine (of 48) British legal origin countries had conscription in 1996. All nine of these had a pretty plain system, namely without buyouts, exemptions for college students, or shorter service terms for college students. Only 2 of the nine (Israel and Sudan) allowed students special provisions for postponing their service. These results, incidentally, are inconsistent with an alternative interpretation of British legal origin, namely that it proxies for greater pro-market sentiment, and therefore a lower incidence of conscription. If that were so, we would expect common law countries to allow more pro-market exceptions, such as buyouts. In fact, they allow fewer of them, consistent with the fixed cost, but not the pro-market sentiment, interpretation. 


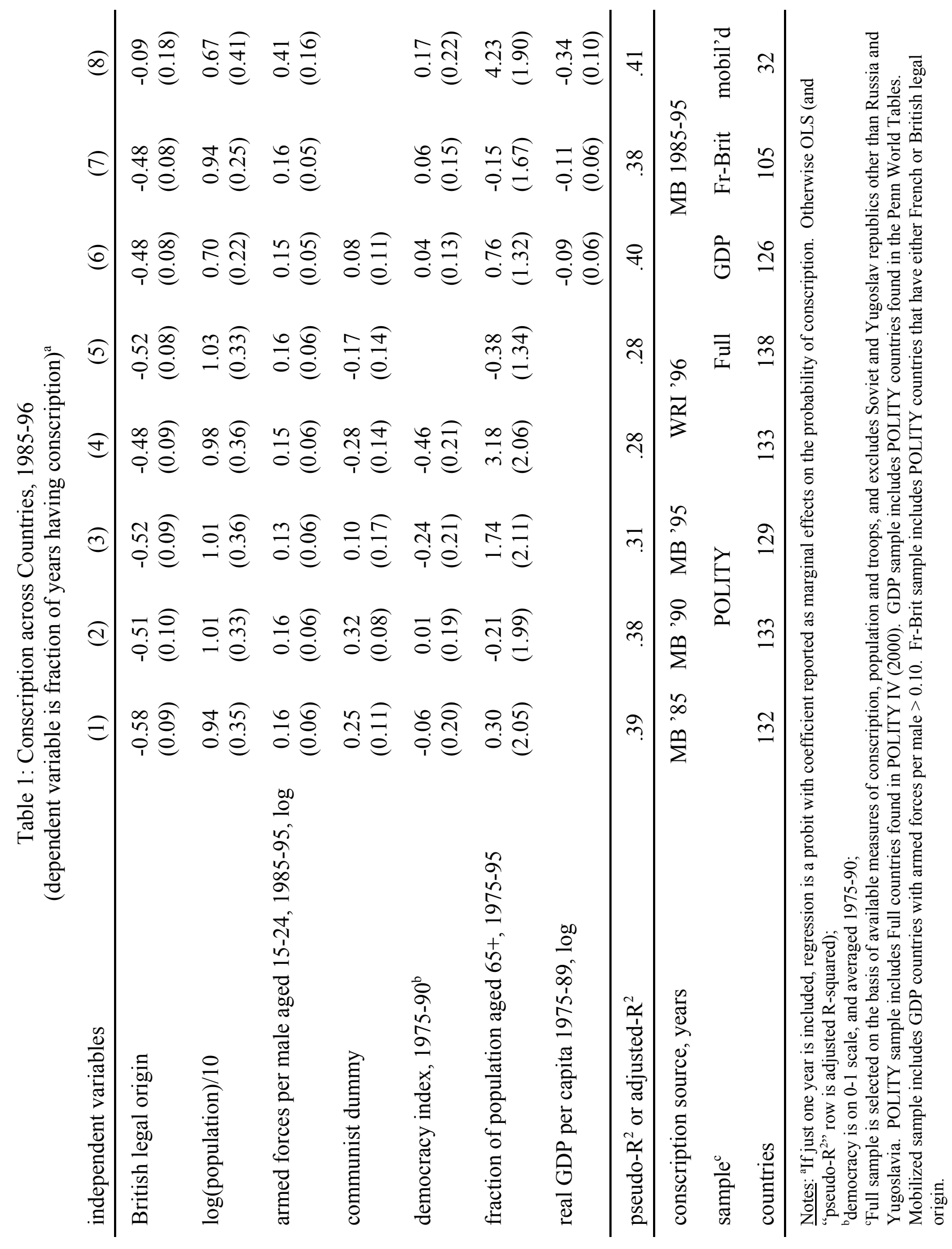


Table 2: Legal Origin and Conscription Systems

(number of countries in each category)

\begin{tabular}{lll} 
conscription system c. 1996 & $\begin{array}{l}\text { British legal } \\
\text { origin }\end{array}$ & other \\
\hline 1. none & 39 & 30 \\
2. plain & 7 & 28 \\
2/3. just postponement option for students & 2 & 27 \\
3. exemption or shorter term for students, but no buyout & 0 & 18 \\
4. legal buyout & 0 & 13 \\
\hline
\end{tabular}

Source: War Resisters' International (1998)

Notes: numbers in the "conscription system" column indicate the category assigned for the purpose of estimating the Table 3's ordered probits. "Just postponement" goes in category 2 or 3, depending on the specification. Illegal buyouts (not shown in the table; none of these 17 countries are British and 10 of them are included among the 18 "exemption" countries) are counted as buyouts in some specifications but not others. Iceland and Panama (neither British) are excluded. 21 former Soviet and Yugoslav republics are included (all drafting, none British, 8 deferring service for college students, 11 exempting some or all service), but only Russia and Yugoslavia are included in the regression tables 1 and 3.

Table 3's specifications (1) - (4) are ordered probits, differing according to the sample used and whether a plain system plus an option for students to postpone (but not shorten or avoid) their service is included in the second or third category. All eight specifications report marginal effects on a probability. For specifications (1), (2), and (4), the reported marginal effects are for the probability of having some kind of conscription. Specification (3) reports marginal effects for the probability of having some kind of selective conscription. Specification (1) uses our full sample of countries having conscription measures and the basic control variables, and shows how small and common law countries tend to be in the lower manpower system categories. An armed force that is large (in per capita terms) tends to be in the higher categories. Democracy and real GDP per capita are not correlated with manpower system. Specification (2) reports similar results when countries with student deferral options are placed in the third category rather than the second. Specification (3) shows similar results for having selective conscription (the categories are universal, exemption, buyout), except that richer and younger countries may be more likely to have selective conscription, even while not more likely to have conscription rather than all-volunteer. 
Specification (4) shows similar results for non-British countries, which are used in specifications (5)-(8).

Specifications (5)-(8) are (dichotomous) probits for the non-British countries using the draft, differing according to the type of conscription system to be predicted. They show the types of countries that use selective rather than universal conscription. The coefficients are similar for all of the columns, except perhaps that using college deferrals or exemptions is easier to predict than using a buyout.

Since few nondemocratic countries have all-volunteer armies (Congo and Saudi Arabia are among them), why it is hard to find support for the democracy theories in Tables 1 and 3? First of all, notice that several communist countries (all drafting) are excluded from the Penn World Tables, and hence from some of our specifications. Table 1's specifications (1)-(5) include the broader set of communist countries and sometimes show an economically and statistically significant effect of communism on conscription. When it comes to the noncommunist, nondemocratic countries, notice that they have larger armed forces and are somewhat less likely to have common law, and are therefore expected to have conscription even if they were democratic.

It is often claimed that democracies do more to redistribute from rich to poor (e.g., de Tocqueville, 1835; Boix, 2003; although see Mulligan, Gil, and Sala-i-Martin, 2004, for a counterargument and supporting evidence). We see no evidence for this in conscription patterns. Table 3 shows that democracies are no less likely to use the volunteer army, or to use a draft system that exempts college students, or to use a draft system that allows sons from rich families to "buy themselves out" of their military service obligation. In fact, heuristic likelihood ratio tests show that our model (ordered $v, u, x$, and $r$ ) and a closely related one (ordered $v, u, r$, and $x$ ) fit the data best out of the twelve possible orderings. The worst fitting ordering is $u, x, v$, and $r$, which is arguably ordered (low to high) in terms of "unfairness," in terms of favoritism to the rich, or pro-market sentiment. $^{16}$

\footnotetext{
${ }^{16} u, v, x$, and $r$ may also be ordered in terms of unfairness; this ordering ranks sixth of the possible twelve. The log likelihood ratio for this model versus ours is 13.6.
} 


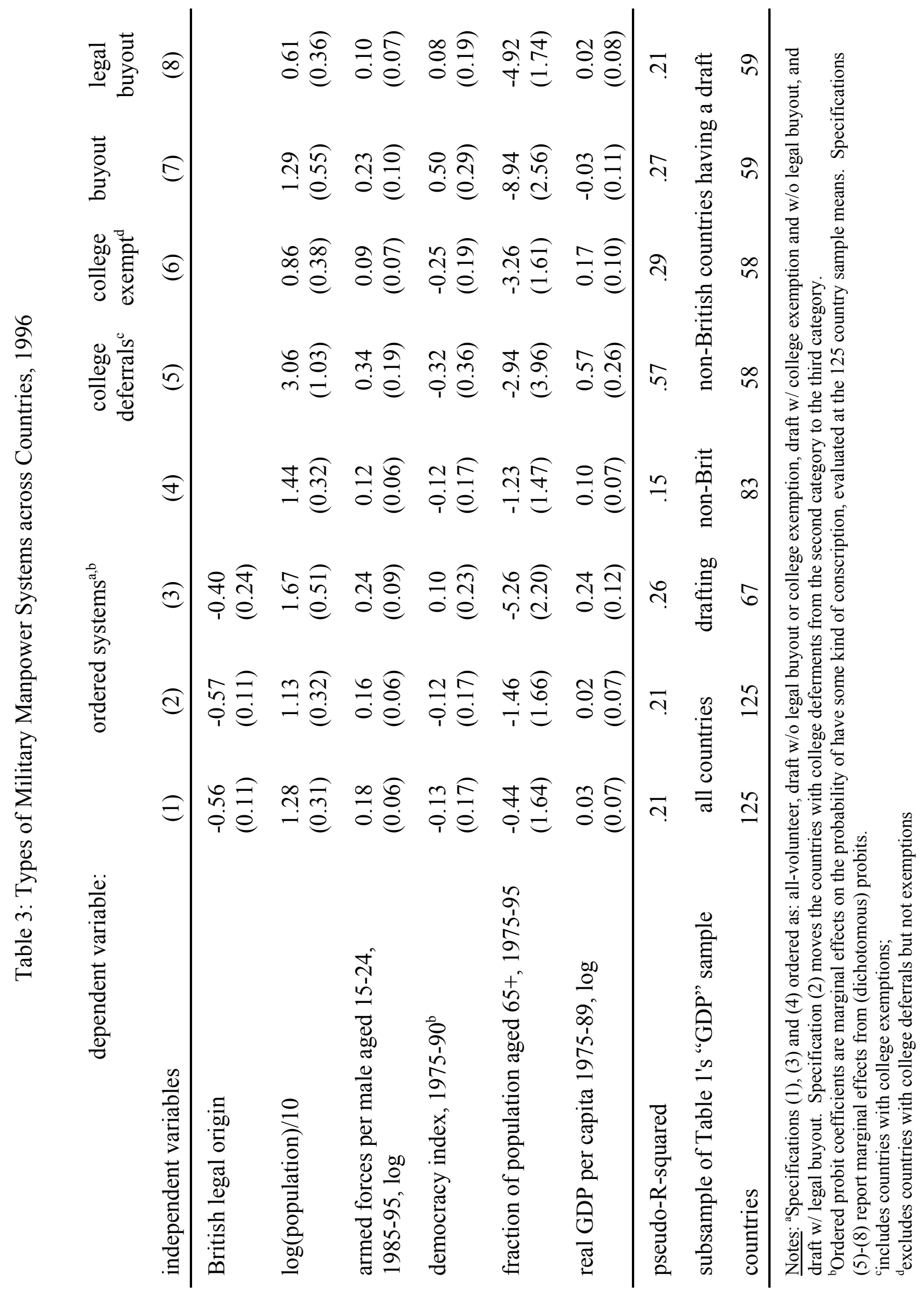




\section{III.C. Alternative Interpretations and Robustness}

The large countries in our data tend to have smaller armies in per capita terms, and a small army raises the question of how to draft a small fraction of the population. Lottery, and short terms of service, are two ways, but we might also expect large countries to use buyouts and exemptions because they need some way to eliminate lots of young men from the service, given that their troop needs are so small relative to the draftable population. Might this, and not fixed costs, explain why population increases the likelihood of using buyouts or exemptions? There are three reasons to think not. First, our regressions hold constant troops per capita. Second, the relation between population and troops per capita is not nearly as strong as the relation between population and the type of military manpower system. Third, Table 3 shows that more troops per capita is associated with more selective conscription systems, not less.

Could our population coefficient be interpreted as evidence that small countries with the draft are especially likely to be mis-coded as not having a draft, because they are small and it is harder and less desirable to obtain good information about their militaries? We give this issue much more attention in a separate data appendix, but here we mention two reasons to suspect that our coding is mainly accurate, even for the small countries. First, we have cross-checked the Military Balance with several other sources, including the United Nations, and War Resisters' International. Second, the small countries in our sample should not be considered anonymous, because Military Balance has for years reported information on their numbers of troops and types of military hardware.

Although not shown in Tables 1 and 3, we have tried several other explanatory variables. Males aged 15-24 as a fraction of total population is marginally significant (with a positive sign) in conscription regressions and ordered probits. Among the small subset of our countries with trade information in the Penn World Tables, $\log (($ exports+imports)/GDP) helps predict conscription (with a positive sign), although including openness does not significantly affect the British coefficient, and increases the magnitude of the log population coefficient. Trade openness may also help predict type of system (more open countries tend to use less complex systems). Conditional on the variables used in Tables 1 and 3, countries with lots of Muslims, and countries that are entholinguistically fractionalized, tend to have more complex conscription systems, but are not especially likely to have conscription rather than all-volunteer. Otherwise, the other variables we have tried - measures of involvement in war, other legal origins, government revenue as a fraction of GDP, average years of schooling, agriculture's share of the labor force, agriculture's share of GDP, fraction of population 
living in urban areas, union density, religion variables, oil country dummies, and a NATO dummy - fail to predict having conscription and type of conscription system. It may seem surprising that years at war does not matter, but notice that countries involved in war tend to have a lot more troops per capita, and troops per capita predict conscription. War does not seem to matter holding troops per capita constant (Ross 1994 had a similar result).

We have also tried replacing log population with 1/population in the specifications shown in Tables 1 and 3. Doing so has no economic or statistically significant affect on the point estimates corresponding to the other independent variables. 1/population may predict conscription slightly better, and selective conscription slightly worse, than does log population. Restricting the sample to countries with at least \$2000 GDP per capita (1985\$) slightly increases the magnitudes of the log population and log armed forces coefficients, and slightly decreases the magnitude of the British coefficient. The log GDP coefficient is larger in this case: -0.24 (s.e. $=0.09) .{ }^{17}$

\section{Conclusion}

We examined patterns of conscription around the world from the perspective of three broad theories. We did not find that democracies are more likely to use conscription. International differences in conscription do not seem to reflect the deadweight costs of taxes, except perhaps among the few countries with very large militaries. On the other hand, we found strong support for the theory that the fixed costs of running a conscription system deter its use. This theory predicts that higher population countries are more likely to use conscription, which is true. It also predicts that countries that regulate other matters and therefore face lower fixed costs of additional government regulation, should use conscription more. When we proxied for the lower level of incremental fixed costs of new regulation using civil law legal origin, we found further support for the theory. Indeed, we examined and found support for a more refined prediction of this theory, namely that higher population countries and civil law countries should be more likely to use elaborate forms of conscription, including special exemptions, replacements, and commutation fees.

\footnotetext{
${ }^{17}$ The larger GDP coefficient is partly due to the fact that the big militaries tend to be in richer countries and thereby get more weight in a sample excluding the poorest countries (see also Table 1, specification (8)).
} 
These results shed light on the patterns of conscription, but they also offer a new interpretation of the pervasive effects of legal origin on regulatory patterns. Previous research has found that, compared to common law countries, French and other civil law countries regulate more heavily in a variety of areas, including entry of new firms (Djankov et al. 2002) and labor markets (Botero et al. 2003). This paper offers an interpretation of this legal origin effect, consistent with Woloch's (1994) account of post-revolutionary France. Specifically, France (and subsequently the countries Napoleon occupied and their colonies) developed a strong centralized administrative state, that intervened in a broad range of activities. Once this system was put in place, the administrative cost of regulating additional activities on a wide-scale was reduced. As a consequence, when faced with incremental social demands, France opted for a regulatory solution across activities, including raising armies. England and its colonies, in contrast, did not develop such pervasive administrative states, and therefore did not opt for regulatory solutions, such as conscription, as reliably. And when common law countries did regulate new areas of life, the intervention was not as comprehensive.

More generally, this evidence points to the neglected but potentially significant role of fixed political and administrative costs in shaping regulatory policies. In our previous work (Mulligan and Shleifer 2003), we argued that such costs determine how much regulation of various activities different U.S. states, as well as different countries, choose to pursue. Both in that paper, and in the present work, we have mentioned political fixed costs, but focused on administrative ones. But political fixed costs may be equally important, and less well understood. Thus, it might take a fixed cost for an interest group to form, but once it forms and the costs of organizing it are sunk, it can be directed to lobby for entirely new causes at a much lower incremental cost than it takes to form a new interest group. Thus trade unions may be formed to pursue wage demands, but then relied on to support protectionist policies; religious coalitions might be organized to pursue social agenda, but then directed to support particular foreign or economic policies. This emphasis on political and not just administrative fixed costs, pursued in different contexts by Campbell (2003), Mulligan and Salai-Martin (1999), and Murphy and Shleifer (2004), might also have significant implications for the adoption of particular public policies. 


\section{Sample Characteristics}

Appendix Table: Characteristics of 133-country sample (Table 1, specification (4))

\begin{tabular}{lllll} 
variable & mean & std. dev. & min & max \\
\hline population (1000s) & 35,273 & 117,094 & 302 & $1,073,255$ \\
log population & 9.10 & 1.55 & 5.71 & 13.9 \\
armed forces per male aged 15-24, 1985-95 & 0.08 & 0.08 & 0.005 & 0.36 \\
log armed forces per male aged 15-24 & -3.02 & 1.01 & -5.34 & -1.01 \\
democracy index, 1975-90 & 0.33 & 0.41 & 0 & 1 \\
fraction of population aged 65+, 1975-95 & 0.06 & 0.04 & 0.01 & 0.17 \\
real GDP per capita 1975-89 (125 countries) & 4,329 & 4,340 & 300 & 17,772 \\
real GDP per capita 1975-89, log & 7.85 & 1.07 & 5.70 & 9.79 \\
\hline
\end{tabular}

dummy variables (fraction of countries having ...)

Communist $=0.17$. Legal origins: British $=0.32$, French $=0.50$, Scandinavian $=0.03$

conscription measures (1996, according to WRI)

countries not drafting: Afghanistan, Australia, Bahrain, Bangladesh, Belgium, Benin, Botswana, Burma, Cambodia, Cameroon, Canada, Chad, Congo Brazzaville, Costa Rica, Djibouti, Dominican Republic, El Salvador, Ethiopia, Fiji, Gambia, Guyana, Haiti, India, Ireland, Ivory Coast, Jamaica, Japan, Kenya, Lesotho, Liberia, Luxembourg, Malawi, Malaysia, Mauritania, Mauritius, Namibia, Nepal, Netherlands, New Zealand, Nicaragua, Nigeria, Oman, Pakistan, Papua New Guinea, Qatar, Rwanda, Saudi Arabia, Sierra Leone, Somalia, South Africa, Sri Lanka, Thailand, Togo, Trinidad and Tobago, United Arab Emirates, United Kingdoms, United States, Uruguay, Zambia, Zimbabwe "universal” draft: Angola, Burundi, Central African Republic, Democratic Republic of Congo, Cuba, Cyprus, Equatorial Guinea, Gabon, Ghana, Guatemala, Guinea, Guinea-Bissau, Honduras, Indonesia, Laos, Madagascar, Mali, Mongolia, Mozambique, Niger, North Korea, Norway, Peru, Philippines, Senegal, Singapore, Switzerland, Tanzania, Uganda, Vietnam, Yemen just postponement option for students: Algeria, Austria, Brazil, Chile, Denmark, Finland, France, Germany, Greece, Hungary, Israel, Italy, Libya, Mexico, Portugal, Romania, South Korea, Spain, Sudan, Sweden, Taiwan, Yugoslavia exemption or shorter term for students, but no buyout: Bulgaria, Columbia, Kuwait, Morocco, Poland, Russia, Venezuela (plus several former Soviet and Yugoslav republics excluded from 133 country sample) legal buyout: Albania, Argentina, Bolivia, China, Ecuador, Egypt, Iran, Iraq, Jordan, Paraguay, Syria, Tunisia, Turkey 


\section{References}

Boix, Carles. Democracy and Redistribution. Cambridge: Cambridge University Press, 2003.

Botero, Juan, et al., “The Regulation of Labor,” NBER Working Paper \#9756, 2003.

Campbell, Andrea Louise. How Policies Make Citizens: Senior Citizen Activism and the American Welfare State. Princeton, NJ: Princeton University Press, 2003.

Carleton, William G. "Raising Armies Before the Civil War." Current History. 54(322), June 1968: 327-32.

Djankov, Simeon, Rafael La Porta, Florencio Lopez-de-Silanes, and Andrei Shleifer, "The Regulation of Entry," Quarterly Journal of Economics 117(1), February: 1-38.

Djankov, Simeon, Edward Glaeser, Rafael La Porta, Florencio Lopez-de-Silanes, and Andrei Shleifer, "The New Comparative Economics," Journal of Comparative Economics 31(4), 595-619.

Fisher, Anthony C. "The Cost of the Draft and the Cost of Ending the Draft." American Economic Review. 59(3), June 1969: 239-54.

Forrest, Alan. Conscripts and Deserters: The Army and French Society during the Revolution and Empire. New York: Oxford University Press, 1989.

Friedman, Milton. "Why Not a Volunteer Army?" New Invidualist Review. Spring 1967: 3-9.

International Institute for Strategic Studies. The Military Balance. London, various issues.

Johnson, William R. "When is a Military Draft Optimal?" manuscript, University of Virginia, January 1990.

Kestnbaum, Meyer. "Citizenship and Compulsory Military Service: The Revolutionary Origins of Conscription in the United States." Armed Forces and Society. 27(1), Fall 2000: 7-36.

La Porta, Rafael, Florencio Lopez-de-Silanes, Andrei Shleifer, and Robert Vishny, "Legal Determinants of External Finance," Journal of Finance 52(3), 1131-1150.

La Porta, Rafael, Florencio Lopez-de-Silanes, Andrei Shleifer, and Robert Vishny, "Law and Finance," Journal of Political Economy 106(6), 1113-1155.

La Porta, Rafael, Florencio Lopez-de-Silanes, Andrei Shleifer, and Robert Vishny, "The Quality of Government," Journal of Law, Economics, and Organization 15(1) : 222-279.

Lee, Dwight R., and Richard B. McKenzie. "Reexamination of the Relative Efficiency of the Draft and the All-Volunteer Army." Southern Economic Journal. 58(3), January 1992: 644-54.

Martin, Donald L. "The Economics of Jury Conscription." Journal of Political Economy. 80(4), 
July 1972: 680-702.

Mjoset, Lars, and Stephen Van Holde. "Killing for the State, Dying for the Nation: An Introductory Essay on the Life Cycle of Conscription into Europe's Armed Forces.” in Lars Mjoset and Stephen Van Holde, eds. The Comparative Study of Conscription in the Armed Forces. Oxford: Elsevier Science, Ltd., 2002.

Moore, Albert Burton. Conscription and Conflict in the Confederacy. Columbia, SC: University of South Carolina Press, 1924 (reprinted 1996).

Mulligan, Casey B. and Xavier X. Sala-i-Martin. "Gerontocracy, Retirement, and Social Security." NBER working paper no. 7117, May 1999.

Mulligan, Casey B., Ricard Gil, and Xavier Sala-i-Martin. "Do Democracies have Different Public Policies than Nondemocracies?" Journal of Economic Perspectives. 18(1), Winter 2004: $51-74$.

Mulligan, Casey B. and Andrei Shleifer. "Population and Regulation.” NBER working paper no. 10234, January 2004.

Murphy, Kevin M. and Andrei Shleifer. "Persuasion in Politics." American Economic Review Papers and Proceedings. 94(2), May 2004.

Ng, Pak Shun, and Casey B. Mulligan. "Measuring Conscription around the World." manuscript, University of Chicago, May 2004.

Oi, Walter. "The Economic Cost of the Military Draft." American Economic Review. 57(2), May 1967: 39-62.

Polity IV Project. Political Regime Characteristics and Transition, 1800-2000. Electronic data file (version p4v2000). College Park, MD: CIDCM, University of Maryland, 2000.

Ross, Thomas W. "Raising an Army: A Positive Theory of Military Recruitment." Journal of Law and Economics. 37(1), April 1994: 109-31.

Sjaastad, Larry A. and Ronald W. Hansen. "The Conscription Tax: An Empirical Analysis." Studies Prepared for the President's Commission on An All-Volunteer Armed Force. Volume II. Washington, DC: U.S. Government Printing Office, 1970.

Summers, Robert and Alan Heston. "The Penn World Table (Mark 5): An Expanded Set of International Comparisons, 1950-1988." Quarterly Journal of Economics. 106(2), May 1991: 327-68.

de Tocqueville, Alexis. "Government of the Democracy in America." in Democracy in America. 
Book 1, Chapter 13, 1835. reprinted by the University of Virginia, $<$ http://xroads.virginia.edu/ HYPER/DETOC/).

United Nations, Commission on Human Rights. "The Question of Conscientious Objection to Military Service." Report of the Sectretary-General submitted pursuant to Commission resolution 1995/83, January 16, 1997.

United Nations, Commission on Human Rights. "Civil and Political Rights, Including the Question of Conscientious Objection to Military Service.” Report of the Sectretary-General submitted pursuant to Commission resolution 1998/77, December 17, 1999.

United States, President's Commission on an All-Volunteer Armed Force. The President's Commission on an All-Volunteer Armed Force. London: Collier-Macmillan, Ltd., 1970.

War Resisters' International. Refusing to Bear Arms: A Worldwide Survey of Conscription and Conscientious Objection to Military Service. London: War Resisters’ International, 1998.

Warner, John T. and Beth J. Asch. "The Economic Theory of a Military Draft Reconsidered." Defense and Peace Economics. 7, 1996: 297-311.

Warner, John T., Beth J. Asch. "The Record and Prospects of the All-Volunteer Military in the United States.” Journal of Economic Perspectives. 15(2), Spring 2001: 169-92.

Woloch, Isser. The New Regime: Transformation of the French Civic Order, 1789-1820s. New York: Norton, 1994. 